\title{
Mechanical Properties, Pozzolanic Activity and Volume Stability of Copper Slag- Filled Cementitious Materials
}

\author{
Junwei SONG ${ }^{1}$, Shenglei FENG ${ }^{1,2}{ }^{*}$, Rongrong XIONG ${ }^{2}$, Yong OUYANG ${ }^{2}$, Qingli ZENG $^{2}$, \\ Jielu ZHU ${ }^{2}$, Chunyuan ZHANG ${ }^{2}$
}

\author{
${ }^{1}$ Nanchang Key Laboratory of Material and Structure Detection, Jiangxi University of Technology, Nanchang 330098, \\ China \\ ${ }^{2}$ College of Civil Engineering, Jiangxi University of Technology, Nanchang 330098, China \\ crossref http://dx.doi.org/10.5755/j01.ms.26.2.21447
}

Received 15 May 2018; accepted 10 November 2018

\begin{abstract}
Copper slag is a by-product waste during copper pyrometallurgy. The piling-stack of copper slag not only occupies a large quantity of plowland, but causes potential danger for local residents. In order to reduce the storage of copper slag, this study prepared concretes by replacing ordinary cement by copper slag. The mechanical properties, phase composition, micrographs, pozzolanic activity and volume stability of the compound cementitious materials were evaluated with fly ash as control. It was found that when the content of copper slag was $5 \%-10 \%$, the best mechanical properties of concretes were obtained. The phase composition of hydration products of copper slag and fly ash based cementitious materials was similar. The micrographs and pozzolanic activity showed that copper slag had stronger reactivity than fly ash. Copper slag based pastes had good volume stability. Copper slag presented a potential application in mortars and concretes. Keywords: mechanical properties, pozzolanic activity, volume stability, copper slag, cementitious materials.
\end{abstract}

\section{INTRODUCTION}

Copper slag (CS) is a metallurgy waste residue generated during the matte smelting process of copper metal [1]. When $1 \mathrm{t}$ of copper is manufactured, $2.2 \mathrm{t}$ of $\mathrm{CS}$ is generated [2]. In China, more than $1,500,000 \mathrm{t}$ of $\mathrm{CS}$ is produced every year. Globally in the year 2015, approximately 68.7 million tons of CS was generated from the world copper industry [3]. These waste copper slags pile up like a mountain, occupying a large amount of plowland. The environmental pollution produced by the large quantity of CS affects the development of local mine areas. How to utilize CS effectively and cleanly, and push green construction, is a major project deserved to study in depth.

Some researches about the application of CS in concretes have been developed. On one hand, CS is studied to substitute the aggregates in mortars and concretes. The literatures show that when CS substitutes the sand in concretes, these concretes have the comparable physical properties with plain concretes [4-6]. The concretes with $\mathrm{CS}$ as fine aggregate have the nearly same compressive and tensile strength with plain concretes. Under proper substitution, the strength of the concretes with CS surpasses that of plain concretes. Brindha D, et al, reported that CS is in favour of the improvement of concrete durability [7]. On the other hand, besides the substitution of fine aggregates in concretes, CS can be used as mineral admixture and replace some quantities of cements, to cut down the costs and protect environment $[8,9]$. I Alp, et al, studied the massive application of CS as raw material in cements [10]. Moura W $\mathrm{A}$, et al, explored the properties such as compressive strength and water-absorbing capacity, and analysed the feasibility of CS used as pozzolanic material in concretes [11]. Caliskan and Behnood showed that the compressive strength of CS coarse aggregate concretes was marginally higher than that of limestone aggregate concretes [12]. However, most of the current researches that the compressive strength of CS coarse aggregate concretes was marginally higher than that of limestone paid attention to the mechanical properties of CS on mortars and concretes. There was a hand of literatures on the mechanism and active intensity of CS used as mineral admixture in cementitious system. In this study, the mechanical properties (including compressive, tensile, flexural strength and stress-strain relation), chemical activity and volume stability of cementitious system incorporating CS are explored. The results may supply more theoretical basis for the application of CS in mortars and concretes.

\section{EXPERIMENTAL}

\subsection{Materials}

Raw materials used in the experiment included copper slag (Jiangxi Tongxing copper factory, China), 42.5 grade Ordinary Portland Cement (OPC, Conch Cement Co., China) and fly ash (FA, class F, obtained from a coal fired power station in Zhengzhou, China). Fly ash powders were collected from coal smoke with a bag dust collector and dried at $105^{\circ} \mathrm{C}$ for $24 \mathrm{~h}$ to reach constant weight before use. CS powders were obtained after 60 min of ball-milling on a planetary mill (QM-2SP20, Nanjing Nanda Instrument Plant, China) with a speed of $300 \mathrm{r} / \mathrm{min}$.

\footnotetext{
*Corresponding author. Tel.: +86-791-88136768; fax: +86-79188136768. E-mail address: 37143565@qq.com (SL. Feng)
} 
Table 1. Chemical composition (wt.\%) and fineness $\left(\mathrm{cm}^{2} / \mathrm{g}\right.$ ) of OPC and mineral admixtures

\begin{tabular}{|c|c|c|c|c|c|c|c|c|c|c|c|c|}
\hline Sample & $\mathrm{SiO}_{2}$ & $\mathrm{Al}_{2} \mathrm{O}_{3}$ & $\mathrm{Fe}_{2} \mathrm{O}_{3}$ & $\mathrm{MgO}$ & $\mathrm{CaO}$ & $\mathrm{Na}_{2} \mathrm{O}$ & $\mathrm{K}_{2} \mathrm{O}$ & $\mathrm{TiO}_{2}$ & $\mathrm{P}_{2} \mathrm{O}_{5}$ & $\mathrm{MnO}$ & $\mathrm{SO}_{3}$ & Fineness \\
\hline OPC & 20.87 & 4.14 & 5.12 & 4.08 & 62.66 & 0.11 & 0.28 & - & - & - & 2.32 & 3289 \\
\hline $\mathrm{CS}$ & 36.66 & 3.84 & 47.12 & 5.33 & 5.57 & 0.64 & 0.37 & 0.28 & 0.11 & 0.09 & - & 2874 \\
\hline FA & 49.03 & 20.12 & 7.9 & 3.35 & 8.72 & 1.46 & 2.29 & 0.8 & 0.48 & 0.1 & - & 2047 \\
\hline
\end{tabular}

Table 2. Mix design of CS concretes

\begin{tabular}{|c|c|c|c|c|c|c|}
\hline Sample & $\mathrm{OPC}, \mathrm{kg} / \mathrm{m}^{3}$ & $\mathrm{CS}, \mathrm{kg} / \mathrm{m}^{3}$ & Fine aggregate, $\mathrm{kg} / \mathrm{m}^{3}$ & Coarse aggregate, $\mathrm{kg} / \mathrm{m}^{3}$ & Water, $\mathrm{kg} / \mathrm{m}^{3}$ & Water-binder ratio \\
\hline $\mathrm{C} 0$ & 317 & 0 & 764 & 1062 & 190 & 0.6 \\
\hline $\mathrm{C} 5$ & 301 & 16 & 764 & 1062 & 190 & 0.6 \\
\hline $\mathrm{C} 10$ & 285 & 32 & 764 & 1062 & 190 & 0.6 \\
\hline $\mathrm{C} 15$ & 269 & 47 & 764 & 1062 & 190 & 0.6 \\
\hline
\end{tabular}

The fineness of raw FA and milled CS was 2047 and $2874 \mathrm{~cm}^{2} / \mathrm{g}$, respectively. The main chemical composition and particle fineness of the three raw materials were shown in Table 1. $\mathrm{Fe}_{2} \mathrm{O}_{3}$ and $\mathrm{SiO}_{2}$ were the main chemical ingredients of CS, determined by X-ray fluorescence (XRF) spectrometry method. The phase composition of milled CS and raw FA was determined by X-ray diffraction (XRD) analysis. The main mineralogical phases were quartz and mullite in $\mathrm{FA}$, while magnetite $\left(\mathrm{Fe}_{3} \mathrm{O}_{4}\right)$ and fayalite $\left(\mathrm{Fe}_{2} \mathrm{SiO}_{4}\right)$ were predominant in $\mathrm{CS}$, shown in Fig. 1.

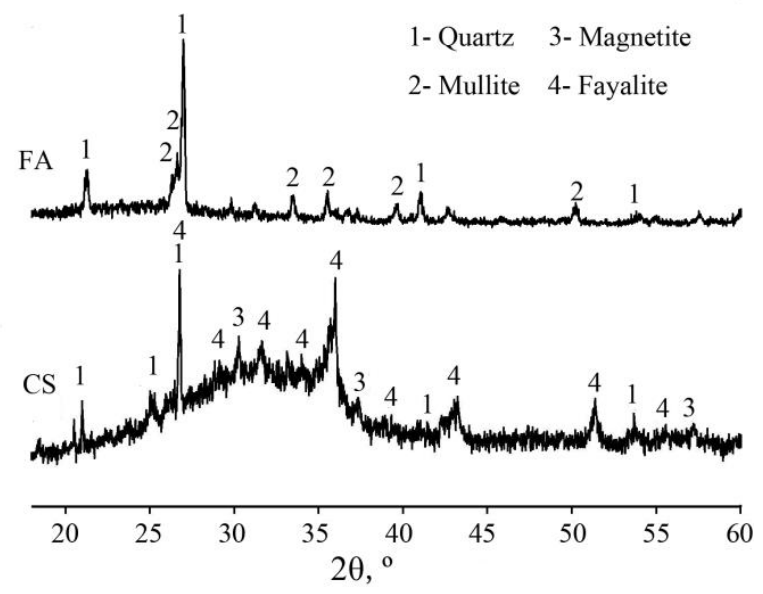

Fig. 1. XRD patterns of milled CS and raw FA

In the concrete experiment for mechanical properties, the OPC cements were substituted by CS in weight with different replacements $(5 \%, 10 \%$ and $15 \%)$, shown in the mix design of Table 2 . The water to binder (OPC+CS) ratio of 0.6 was used for all concrete admixtures with the slump of around $160 \mathrm{~mm}$, according to the Chinese Standard GB/T 50080-2016 [13]. The weight ratio of binder, fine aggregate and coarse aggregate was 1:2.41:3.35. The coarse aggregate with a nominal maximum size of $14 \mathrm{~mm}$ was crushed granite; while the fine aggregate was natural sand with moisture content of $6 \%$, the particle size of $0.3-1.1 \mathrm{~mm}$ and the fineness modulus of 2.91 .

In the experiment to test pozzolanic activity of CS, two kinds of cementitious system, namely CS-Calcium hydroxide-water (CS-CH) and FA-Calcium hydroxidewater $(\mathrm{FA}-\mathrm{CH})$ were prepared according to the mix design of Table 3. The water ratio of 0.4 was fixed with the paste fluidity of $90 \mathrm{~mm}$, in accordance with Chinese Standard
GB/T 8007-2012 [14]. Deionized water was used to eliminate impurities influence.

Table 3. Composition of compound cementitious system

\begin{tabular}{|c|c|c|c|c|}
\hline Sample & CH, t. $\%$ & CS, wt.\% & FA, wt.\% & $\begin{array}{c}\text { Water-binder } \\
\text { ratio }\end{array}$ \\
\hline CS-CH & 25 & 75 & 0 & 0.4 \\
\hline FA-CH & 25 & 0 & 75 & 0.4 \\
\hline
\end{tabular}

\subsection{Methods}

After curing age of 7 and 28 days in a standard curing chamber, the concrete samples with size of $100 \mathrm{~mm} \times 100 \mathrm{~mm} \times 100 \mathrm{~mm}$ were used to test compressive strength using a hydraulic $2000 \mathrm{kN}$ press machine with the loading speed of $2500 \mathrm{~N} / \mathrm{s}$, following the Chinese Standard GB 50081-2002 [15]. The dimensions of samples for splitting tensile strength and flexural strength were $100 \mathrm{~mm} \times 100 \mathrm{~mm} \times 100 \mathrm{~mm}$ and $100 \mathrm{~mm} \times 100 \mathrm{~mm} \times 400 \mathrm{~mm}$, respectively. For each curing age, triplicates for mechanical strengths were conducted. The stress-strain behavior was tested on the prism specimens $(100 \mathrm{~mm} \times 100 \mathrm{~mm} \times 300 \mathrm{~mm})$ after curing of 28 days, by using a MTS electronic universal testing machine with a capacity of $3000 \mathrm{kN}$. The load was controlled by displacement, and the loading rate was fixed at $0.003 \mathrm{~mm} / \mathrm{s}$.

The samples $(20 \mathrm{~mm} \times 20 \mathrm{~mm} \times 20 \mathrm{~mm})$ were prepared according to the mix of Table 3 , removed after shaping for 1 day in a curing box, and then cured hermetically to predetermined curing time. The samples were immersed in acetone (Sinopharm, China) to stop hydration. After broken, grind, and dried, the samples were test for X-ray diffraction (XRD), thermogravimetrydifferential thermogravimetry/ differential scanning calorimetry (TG-DTG/DSC) and scan electron morphology (SEM). XRD was carried out by an X-ray diffractometer (X'Pert PRO, PANalytical Co., the Netherlands), employing $\mathrm{CuK} \alpha$ radiation $(1.54 \AA)$. The instrument voltage and current were set as $40 \mathrm{kV}$ and $40 \mathrm{~mA}$, respectively. The $2 \theta$ range was from $5^{\circ}$ to $60^{\circ}$ with $0.013^{\circ}$ step size and $10 \mathrm{~s}$ step time. The thermal analysis was carried out on a MettlereToledo 850 apparatus at ranges of $35-1000^{\circ} \mathrm{C}$ (alumina crucible), with the heating rate being $10^{\circ} \mathrm{C} / \mathrm{min}$ in air atmosphere. SEM micrographs were taken with a field emission scanning electron microscope (Nova 430, FEI, the 
Netherlands). The samples were sputter-coated with gold before observation.

The expansion rate conforming to China Standard GB/T 750-92 [16], was used to evaluate the volume stability of pastes with OPC replaced by copper slag (eg. $0 \%, 20 \%$, $30 \%, 40 \%, 50 \%$ and $60 \%$ in weight) or fly ash (eg. $50 \%$ and $60 \%$ in weight). In the soundness test, one-day age specimens $(25 \mathrm{~mm} \times 20 \mathrm{~mm} \times 280 \mathrm{~mm})$ were maintained for 3 hours in an autoclave with pressure of $2 \pm 0.05 \mathrm{MPa}$ after boiling under constant temperature of $100{ }^{\circ} \mathrm{C}$ and relative humidity of $100 \%$.

\section{RESULTS AND DISCUSSION}

\subsection{Mechanical strengths}

Fig. 2 demonstrates the mechanical strengths of concretes with different CS contents after 7 and 28 days of curing. In Fig. 2 a, with the increasing contents of CS, the compressive strength of concretes after curing of 7 days decreased, from 34.3 MPa of C0 to 28.7 MPa of C15. The compressive strength after curing of 28 days increased from $40.4 \mathrm{MPa}$ of $\mathrm{C} 0$ and peaked with $43.2 \mathrm{MPa}$ of $\mathrm{C} 5$, then decreased to $33.3 \mathrm{MPa}$ of $\mathrm{C} 15$. The variation trend of tensile and flexural strengths of concretes with different CS contents after 7 and 28 days of curing was similar with the compressive strength of 28 days. The tensile and flexural strengths increased from $\mathrm{C} 0$ and peaked at $\mathrm{C} 5$, then deceased to $\mathrm{C} 15$. The tensile strength of $\mathrm{C} 5$ and $\mathrm{C} 10$ was nearly the same, while the flexural strength of C5 was slightly more than that of C10. Mineral admixtures can improve the concrete compressive strength, because of admixture chemical and physical effect [17]. The fine CS improved the particle distribution of cementitious system, and then enhanced the concrete compressive strength. Meanwhile, the copper slags with chemical activity reacted with $\mathrm{CH}$ of cement hydration products, which also enhanced the concrete compressive strength. However, the second hydration rate of mineral admixtures was relatively lower and mainly generated in the late hydration. The over CS substitution decreased the cement content and adversely affected the concrete compressive strength.

After 7 days of curing, the decreased compressive strength with the increased CS contents was due to the limited physical effect and low chemical activity of CS. This effect and activity could not remedy the adverse impact of decreased cement content. Whereas, after 28 days of curing, the increased mechanical strengths of concretes with
$5 \%-10 \%$ CS might be owe to the enhanced chemical activity of CS. But the too much replacement of CS at C15 sample could not bring the cement superiority because of the too limited content of Portland cements.

Brittleness is a kind of property of rupture with little deformation under external force. Normally, concretes have weak brittleness. In concrete engineering application and tests, brittleness index, namely the division of compressive strength by tensile strength (or flexural strength), is used to characterize the brittleness of concretes [18]. Fig. 3 shows the brittleness index of concretes with different CS contents. $\mathrm{R}_{\mathrm{c} / \mathrm{t}}$ denotes the brittleness index of the division of compressive strength by tensile strength, whilst $R_{\mathrm{c} / \mathrm{f}}$ denotes that of the division of compressive strength by flexural

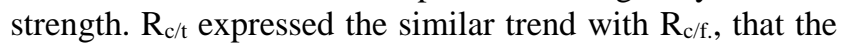
brittleness of 7 days curing decreased with the increased content of CS, reached the lowest at $10 \% \mathrm{CS}$ content and increased when $15 \% \mathrm{CS}$ content. In the early curing age, the compressive strength progressed fast and the formed C$\mathrm{S}-\mathrm{H}$ (hydrated calcium silicate) increased with the increased CS contents, which made the strong roughness. For $15 \%$ CS content, the less C-S-H was formed because of the over replacement of cements by CS. After 28 days of curing, the Rc/t and Rc/f expressed the same trend that the brittleness increased peaked at $5 \% \mathrm{CS}$, and then decreased. In the late curing age, the compressive strength increased slowly; while the formed C-S-H gel transformed to crystallizes.

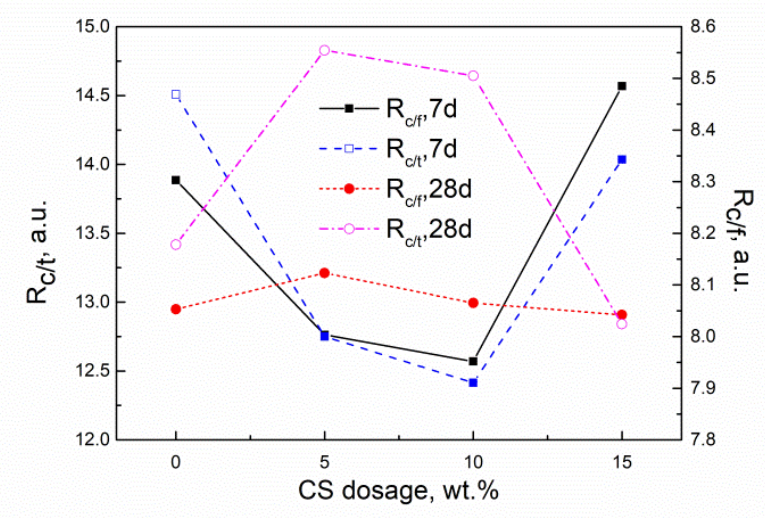

Fig. 3. Brittleness index of concretes with different copper slag contents

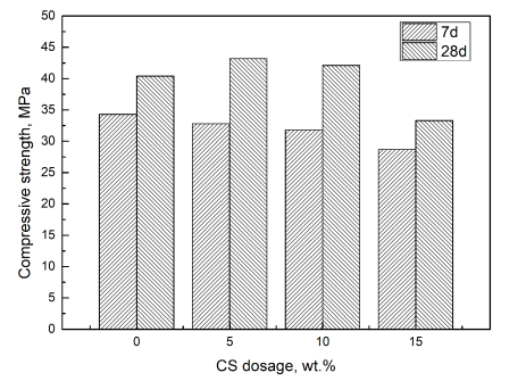

a

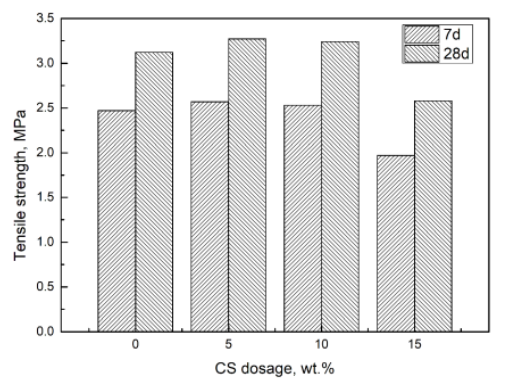

b

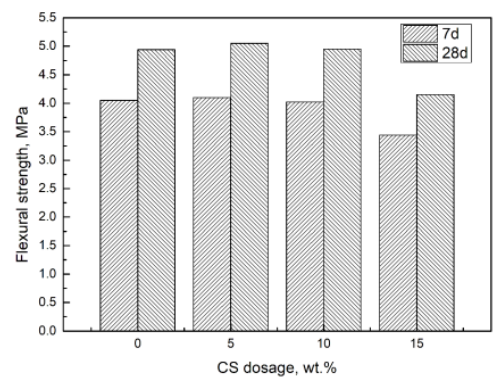

c

Fig. 2. Mechanical strengths of concretes with different CS contents: $a$-compressive strength; b-tensile strength; c-flexural strengt 
Because of the least C-S-H gel in 5\% CS specimen, its brittleness was the strongest and its roughness was the weakest. Also, the $R_{c / t}$ and $R_{c / f}$ both can denote the brittleness index, due to the similar trend.

Fig. 4 depicts the uniaxial compressive stress-strain curve of concretes with different copper slag contents after 28 days of curing. The stress-strain curve demonstrated a typical brittle damage, with a smaller strain and a sudden fracture. Also, it can be seen that C5 had a higher compressive strength and elastic module than $\mathrm{C} 0$, demonstrating that the smaller content of copper slag can improve the compressive strength and elastic module of concretes. This might be due to the filling effect of copper slags in concrete. When OPC is replaced by copper slag in the same weight of $5 \mathrm{wt} . \%$, copper slag can fill in the pores between hydration products and aggregates, and increase the compressive strength and elastic module. Our result is consistent with the literature [19]. For the breaking point in C5 stress-stain curve, the C5 concrete has less C-S-H gel produced by the less OPC, resulting in the bad ductility. When the replacement of copper slag in OPC surpasses a certain value, the elastic module of concretes with copper slag will decline, compared to concrete prepared by pure cement. Zain attributed the lower elastic module to the retardation of cement hydration due to the presence of heavy metals in copper slag [20]. Benson considered that the very fine particles of the slag supplied a large amount of surface area per unit volume to be coated with cement, which might effectively have reduced the amount of cement available for binding the fine and coarse aggregates [21]. Besides these reasons, we thought that for $\mathrm{C} 10$ specimens, the elastic module is lower than that of $\mathrm{C} 0$, possibly due to the less $\mathrm{C}$ $\mathrm{S}-\mathrm{H}$ produced in the concretes.

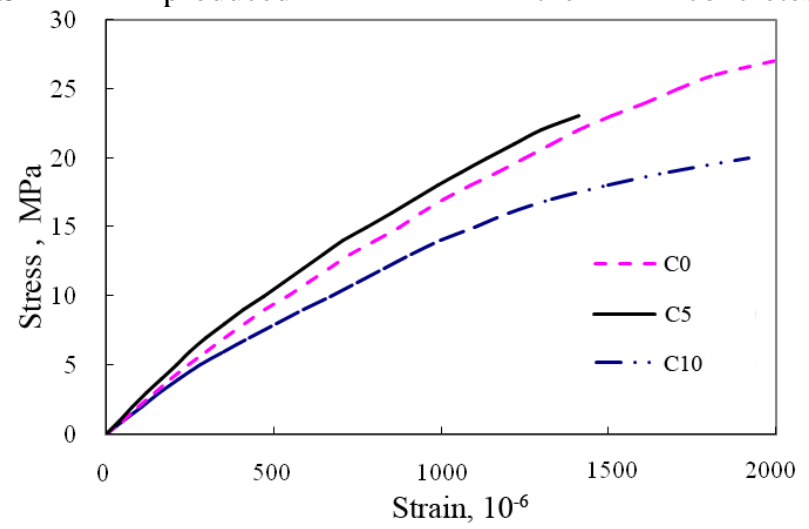

Fig. 4. Stress-strain curve of concretes with different copper slag contents
$\mathrm{C}_{3} \mathrm{~S}$ (tricalcium silicate) and $\mathrm{C}_{2} \mathrm{~S}$ (dicalcium silicate) in $\mathrm{OPC}$ can generate a large quantity of C-S-H gel and $\mathrm{Ca}(\mathrm{OH})_{2}$ crystal by hydration reaction. Although active $\mathrm{SiO}_{2}$ in copper slag can produce C-S-H gel via second hydration reaction with $\mathrm{Ca}(\mathrm{OH})_{2}$ crystal, and $\mathrm{Fe}_{3} \mathrm{O}_{4}$ can hydrate to produce $\mathrm{Fe}(\mathrm{OH})_{3} / \mathrm{Fe}(\mathrm{OH})_{2}$ gel (clarified in Section 3.2), the gel is comparatively less when copper slag replaces OPC in the same weight.

The stress-strain curve, graphed constitutive relation, plays an important role in studying the structure and force analysis of concretes. So it is needed to construct the constitutive models. The stress-strain curve can be expressed as a dimensionless coordinate:

$x=\varepsilon / \varepsilon_{c}, y=\sigma / \sigma_{c}$.

Thereinto, $\varepsilon-$ the stress, $\varepsilon_{\mathrm{c}}-$ the peak stress, $\sigma-$ the strain, $\sigma_{c}-$ the peak strain. Then a standard curve with point coordinate $(1,1)$ is plotted. Guo et al. deeply studied the constitutive relation of concretes and came up with a Guo's model [22]. In Guo's model, the stress-strain curve can be fitted as a polynomial for the ascent stage and a rational fraction for the descent stage:

$$
\left\{\begin{array}{cc}
y=a x+(3-2 a) x^{2}+(a-2) x^{3} & x \leq 1 \\
y=\frac{x}{b(x-1)^{2}+x} & x \geq 1
\end{array}\right. \text {. }
$$

In Eq. 2, $\mathrm{a}$ and $\mathrm{b}$ are constants to be determined. By using Eq. 2, the constitutive relation of concretes with different copper slag contents is resolved. Because of the only ascent stage of the stress- strain curve, only the parameter, a, is determined, as shown in Table 4.

Table 4. The value of parameter a

\begin{tabular}{|c|c|c|c|}
\hline sample & C0 & C5 & C10 \\
\hline $\mathrm{a}$ & 1.147 & 1.023 & 1.413 \\
\hline
\end{tabular}

The stress-strain curves and the fitted curves in light of Eq. 2 are compared in Fig. 5. It can be seen the fitted curves nearly coincided with the tested stress-strain curves. It demonstrates that the Guo's model can be used to analyze the constitutive relation of concretes with different copper slag contents.

\subsection{Phase composition}

If there were a quantity of active $\mathrm{SiO}_{2}$ and $\mathrm{Al}_{2} \mathrm{O}_{3}$ in the mineral admixtures, these active composites could react with $\mathrm{Ca}(\mathrm{OH})_{2}$ to generate C-S-H gel.
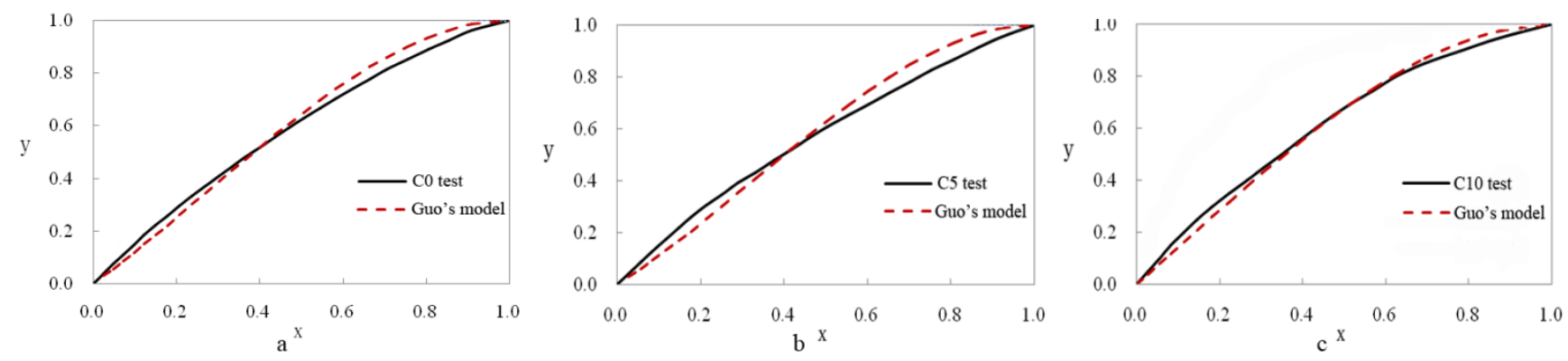

Fig. 5. Constitutive relationship of concretes with different copper slag contents 
Such mineral admixtures were considered to have pozzolanic activity (good chemical activity). To verify the pozzolanic activity of CS, CS-CH samples were prepared in accordance to Table 3 with FA-CH as a control sample.

Fig. 6 shows the XRD patterns of CS-CH and FA-CH samples cured after 28 days. Besides the existence of $\mathrm{CH}$ in the hydration products of CS-CH and FA-CH, C-S-H and carbonated $\mathrm{CaCO}_{3}$ were also detected, which demonstrated that CS had a kind of pozzolanic activity similar to FA. C$\mathrm{S}-\mathrm{H}$ was produced from the reaction of active $\mathrm{SiO}_{2}$ in $\mathrm{CS}$ or FA and $\mathrm{Ca}(\mathrm{OH})_{2}$.

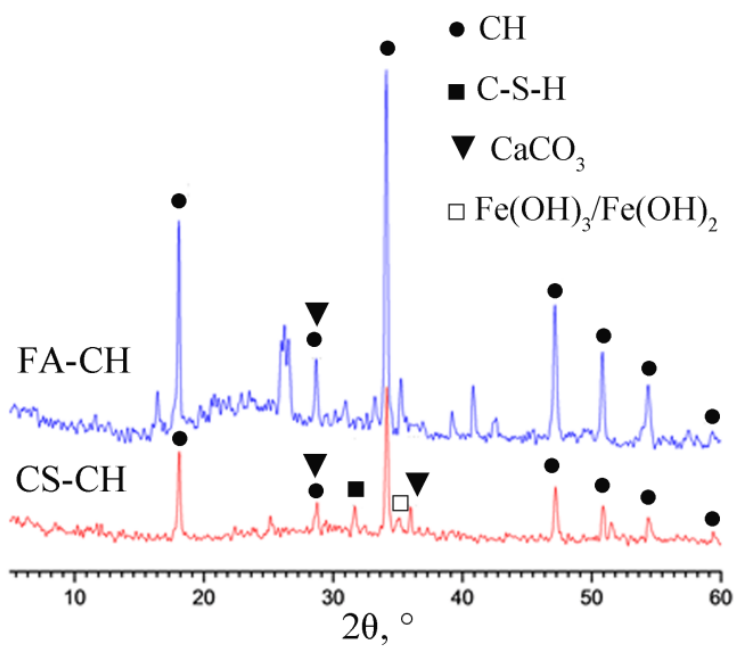

Fig. 6. XRD patterns of hydration products from $\mathrm{CS}-\mathrm{CH}$ and FA-CH

The presence of $\mathrm{CaCO}_{3}$ was because of the carbonation of $\mathrm{Ca}(\mathrm{OH})_{2}$ in atmosphere. Moreover, the characteristic peak intensity of $\mathrm{CH}$ in $\mathrm{CS}-\mathrm{CH}$ hydration products was weaker than that of FA-CH, demonstrating that more $\mathrm{CH}$ in $\mathrm{CS}-\mathrm{CH}$ cementitious system was consumed, and that the pozzolanic activity of $\mathrm{CS}$ was stronger that FA. The characteristic peak intensity of C-S-H in CS-CH hydration products was stronger than that of $\mathrm{FA}-\mathrm{CH}$, which was due to the faster reaction rate in more active $\mathrm{CS}-\mathrm{CH}$ system, and the more hydration products (C-S-H) after 28 days of curing. Besides $\mathrm{C}-\mathrm{S}-\mathrm{H}$ gel found in the hydration products of CS-CH system, $\mathrm{Fe}(\mathrm{OH})_{3} / \mathrm{Fe}(\mathrm{OH})_{2}$ gel was generated, due to the $\mathrm{Fe}_{3} \mathrm{O}_{4}$ hydration reaction. The XRD patterns illustrated the stronger pozzolanic activity of CS than FA.

The DSC-TG curves of CS-CH and FA-CH after 28 days of curing is presented in Fig. 7. In the DSC curves, there are three obvious endothermic valleys between $30{ }^{\circ} \mathrm{C}$ and $1000^{\circ} \mathrm{C}$. The first endothermic valley happened below $200{ }^{\circ} \mathrm{C}$, demonstrating the loss of absorbed water, the dehydration of $\mathrm{C}-\mathrm{S}-\mathrm{H}$ and $\mathrm{Fe}(\mathrm{OH})_{3} / \mathrm{Fe}(\mathrm{OH})_{2}$ gel $[23,24]$. The second endothermic valley in $400-500{ }^{\circ} \mathrm{C}$ was due to the decomposition of unhydrated $\mathrm{Ca}(\mathrm{OH})_{2}$. The last endothermic valley took place at about $700{ }^{\circ} \mathrm{C}$, which meant the decomposition of $\mathrm{CaCO}_{3}$. The existence of C-S-H gel, $\mathrm{Ca}(\mathrm{OH})_{2}$ and $\mathrm{CaCO}_{3}$ was in accordance to the XRD detection in Fig. 6. The area of the endothermic valley below $200{ }^{\circ} \mathrm{C}$ of $\mathrm{CS}-\mathrm{CH}$ was bigger than that of $\mathrm{FA}-\mathrm{CH}$, which demonstrated more $\mathrm{C}-\mathrm{S}-\mathrm{H}$ gel in $\mathrm{CS}-\mathrm{CH}$ than FA$\mathrm{CH}$. The endothermic valley in $400-500{ }^{\circ} \mathrm{C}$ in $\mathrm{CS}-\mathrm{CH}$ was smaller than that of FA-CH, meaning that $\mathrm{CS}$ reacted with more $\mathrm{Ca}(\mathrm{OH})_{2}$ and showed a stronger pozzolanic activity.

In DSC curves, the characteristic peaks in $400-500{ }^{\circ} \mathrm{C}$ were sole and clear. So the content, $\mathrm{W}_{1}$, of $\mathrm{Ca}(\mathrm{OH})_{2}$ could be calculated according to TG curves.

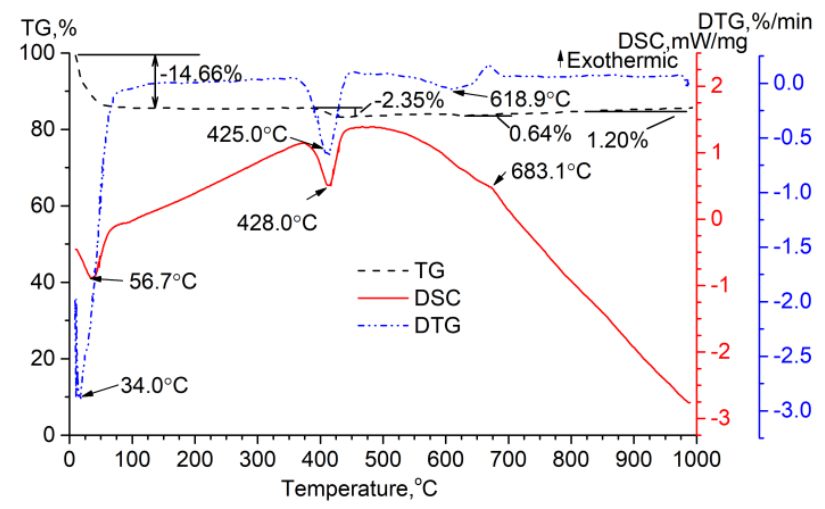

a

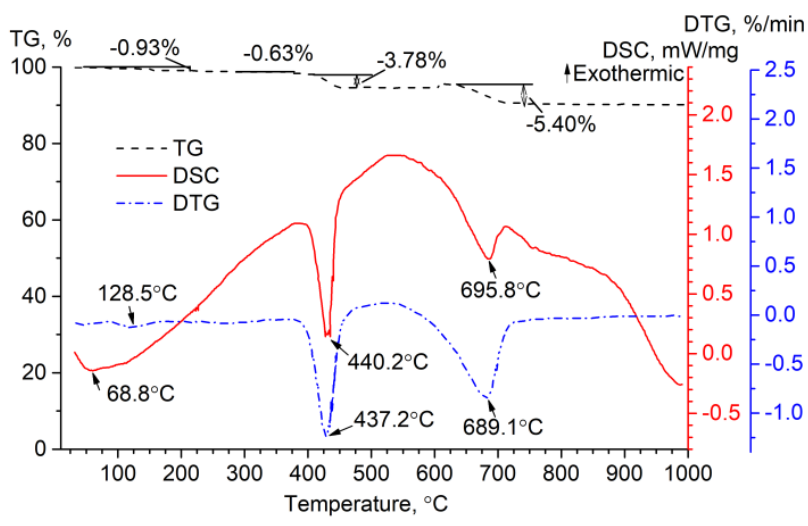

b

Fig. 7. TG, DTG and DSC curves after 28 days of curing of: $\mathrm{a}-\mathrm{CS}-\mathrm{CH} ; \mathrm{b}-\mathrm{FA}-\mathrm{CH}$

In Table 3, the content of $\mathrm{Ca}(\mathrm{OH})_{2}$ in the system including $\mathrm{CS}$ or $\mathrm{FA}, \mathrm{CH}$, and water was $17.9 \mathrm{wt} \%$ $(=25 \div(100+40) \times 100 \mathrm{wt} . \%)$. Thus, the content of reacted $\mathrm{Ca}(\mathrm{OH})_{2}, \alpha$, was shown in Table 5. The bigger value of $\alpha$ meant the more intense hydration action in samples. After 28 days of curing, the reacted $\mathrm{CH}$ content $(45.9 \%)$ in $\mathrm{CS}-\mathrm{CH}$ samples was more than the reacted $\mathrm{CH}$ content $(13.0 \%)$ in FA-CH samples, demonstrating the stronger pozzolanic activity of CS than FA.

Table 5. Hydration degree of CS-CH and FA-CH

\begin{tabular}{|c|c|c|c|}
\hline Sample & Age (day) & $\mathrm{W}_{1}, \%$ & $\alpha, \%$ \\
\hline CS-CH & 28 & 9.7 & 45.9 \\
\hline FA-CH & 28 & 15.5 & 13.0 \\
\hline
\end{tabular}

\subsection{Morphology of hydration products}

Fig. 8 shows the SEM images of raw materials and hydration products after 28 days of curing. The CS presented irregular shape, with compact structure and rough surface, as shown in Fig. 8 a. FA particles were spherical shape with glossy surface, as shown in Fig. 8 c. Fig. 8 b showed that after 28 days of curing, most surfaces of CS were obviously eroded, and compact gel substances were 
shaped on the CS surface, demonstrating that CS reacted with $\mathrm{CH}$ to generate $\mathrm{C}-\mathrm{S}-\mathrm{H}$ gel and enhanced the concrete compressive strength. However, as shown in Fig. 8 d, the FA particles were dispersed, and kept the original appearance, without being eroded, which illustrated that FA had weaker pozzolanic activity than CS.

Table 6. Volume stability of pastes with cement replaced by CS and FA at different contents

\begin{tabular}{|c|c|c|c|c|c|c|c|}
\hline \multicolumn{5}{|c|}{ CS content, wt.\% } & \multicolumn{2}{c|}{$\begin{array}{c}\text { FA content, } \\
\text { wt.\% }\end{array}$} \\
\hline 0 & 20 & 30 & 40 & 50 & 60 & 50 & 60 \\
\hline 0.052 & 0.025 & 0.012 & 0.004 & -0.010 & -0.032 & 0.023 & 0.025 \\
\hline
\end{tabular}
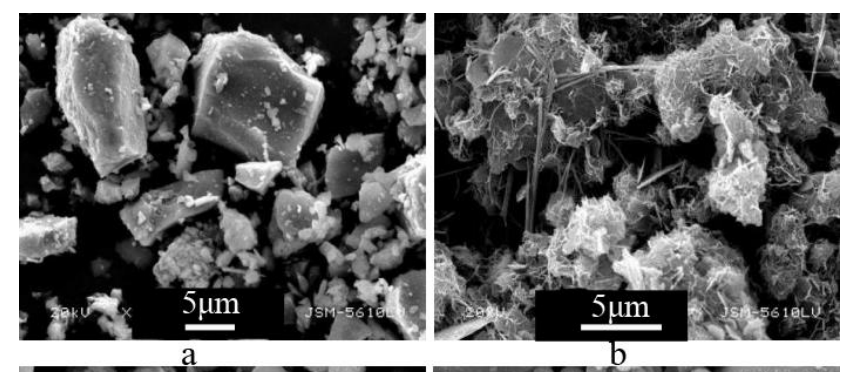

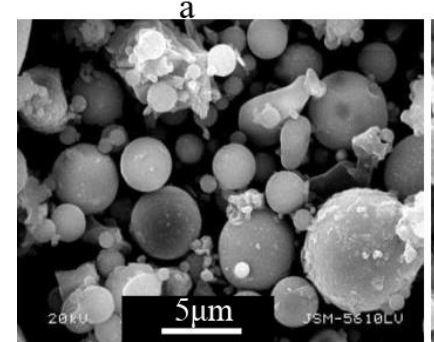

c

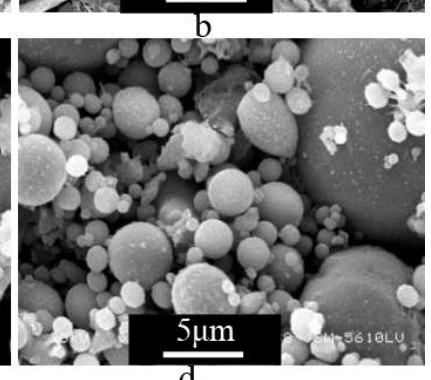

d
Fig. 8. SEM images of raw materials and hydration products after 28 days of curing: $a$-raw material of $\mathrm{CS} ; \mathrm{b}$-hydration products of $\mathrm{CS}-\mathrm{CH}$; $\mathrm{c}$-raw material of $\mathrm{FA}$; d-hydration products of FA-CH

\subsection{Volume stability}

In cementitious system, the content of $\mathrm{CaO}, \mathrm{MgO}$ and limestone is much crucial to the volume stability of the system [25 - 27]. It could be seen from Table 1 that $\mathrm{MgO}$ in CS was 5.33 wt. \%, with 3.35 wt.\% in FA and 4.08 wt.\% in cement. Therefore, it should consider the effect of $\mathrm{MgO}$ content on the volume stability of the cementitious system in the application of CS.

To explore the volume stability of CS cementitious system, cement was equally replaced by CS of 20-60 wt.\%, or FA of 50-60 wt.\%. The result was shown in Table 6. In plain cement, the instability of cement paste took place because of the volume expansion caused by $\mathrm{Ca}(\mathrm{OH})_{2}$ and $\mathrm{Mg}(\mathrm{OH})_{2}$, when $\mathrm{f}-\mathrm{CaO}$ and $\mathrm{f}-\mathrm{MgO}$ hydrated with water. Compared to plain cement, cement with mineral admixtures (CS or FA) had lower expansion rate (no more than $0.5 \%$ ), which would not cause any instability. Some literatures reported that no $\mathrm{f}-\mathrm{Cao}$ and $\mathrm{f}-\mathrm{MgO}$ was found in $\mathrm{CS}$. Nevertheless RO phase including divalent metal oxides, such as $\mathrm{FeO}, \mathrm{MgO}, \mathrm{MnO}$ and $\mathrm{CaO}$, existed as solid solution in CS, which was more stable and would not hydrate even under high temperature and pressure $[28,29]$. According to the aforemensioned hydration tests, CS had strong pozzolanic activity, and could react with about half of $\mathrm{Ca}(\mathrm{OH})_{2}$ in the cement paste, which vastly reduced the
$\mathrm{Ca}(\mathrm{OH})_{2}$ content. With the increase of $\mathrm{CS}$ in cement, the less of $\mathrm{f}-\mathrm{CaO}$ and $\mathrm{f}-\mathrm{MgO}$, and the lower expansion rate of the cement paste. In a word, the cement paste with CS had good volume stability.

\section{CONCLUSIONS}

The feasibility of cement equally replacement by copper slag was explored on the mechanical strengths, pozzolanic activity and volume stability. The result showed that copper slag had stronger pozzolanic activity than fly ash and could react with $\mathrm{Ca}(\mathrm{OH})_{2}$ to generate $\mathrm{C}-\mathrm{S}-\mathrm{H}$ gel and enhance the concrete mechanical strength, when copper slag content was less than 15 wt.\%. Compared to fly ash, the pozzolanic activity of copper slag was manifested earlier, and the reactive rate was faster. Moreover, the pozzolanic activity of copper slag was stronger, and copper slag could react with about half of $\mathrm{Ca}(\mathrm{OH})_{2}$ in the pastes. Though the high $\mathrm{MgO}$ content in copper slag, the cement pastes with copper slag had good volume stability, due to the lower $\mathrm{Ca}(\mathrm{OH})_{2}$ content in the pastes. These results manifested that copper slag had good mechanical strength, pozzolanic activity and volume stability, demonstrating that copper slag had potential application in cements and concretes.

\section{Acknowledgment}

The authors would like to thank the National Natural Science Foundation of China (51668021), Natural Science Foundation of Jiangxi Province (20171BAB206052), Foundation of Jiangxi Educational Committee (GJJ171020), Natural Science Project of Jiangxi University of Technology (ZR1803) and also wish to acknowledge Nanchang Knowledgement Innovative Team of Green and Energy Conservation Building, Nanchang Guided Science and Technology Project for their generous assistance throughout the experimental program.

\section{REFERENCES}

1. Sharma, R., Khan, R.A. Sustainable use of Copper Slag in Self Compacting Concrete Containing Supplementary Cementitious Materials Journal of Cleaner Production 151 2017: pp. $179-192$. https://doi.org/10.1016/j.jclepro.2017.03.031

2. Shi, C., Meyer, C., Behnood, A. Utilization of Copper Slag in Cement And Concrete Resources, Conservation and Recycling 52 (10) 2008: pp. 1115-1120. https://doi.org/10.1016/j.resconrec.2008.06.008

3. Sharma, R., Khan, R.A. Influence of Copper Slag and Metakaolin on the Durability of Self Compacting Concrete Journal of Cleaner Production 171 2017: pp. $1171-1186$. https:// doi.org/10.1016/j.jclepro.2017.10.029

4. Behnoo, A., Gharehveran, M.M., Asl, F.G., Ameri, M. Effects of Copper Slag and Recycled Concrete Aggregate on the Properties of CIR Mixes with Bitumen Emulsion, Rice Husk Ash, Portland Cement and Fly Ash Construction and Building Materials 96 2015: pp. 172-180. https://doi.org/10.1016/j.conbuildmat.2015.08.021

5. Al-Jabri, K.S, Al-Saidy, A.H., Taha, R. Effect of Copper Slag as a Fine Aggregate on the Properties of Cement Mortars and Concrete Construction and Building Materials 25 (2) 2011: pp. $933-938$. 
https://doi.org/10.1016/j.conbuildmat.2010.06.090

6. Khanzadi, M., Behnood, A. Mechanical Properties of HighStrength Concrete Incorporating Copper Slag as Coarse Aggregate Construction and Building Materials 23 (6) 2009: pp. $2183-2188$.

https://doi.org/10.1016/j.conbuildmat.2008.12.005

7. Brindha, D., Nagan, S. Durability Studies on Copper Slag Admixed Concrete Asian Journal of Civil Engineering (Building and Housing) 12 (5) 2011: pp. 563-578. https://ajce.bhrc.ac.ir/Portals/25/PropertyAgent/2905/Files/6 027/563.pdf

8. Najimi, M., Sobhani, J., Pourkhorshidi, A.R. Durability of Copper Slag Contained Concrete Exposed to Sulfate Attack Construction and Building Materials 25 (4) 2011: pp. $1895-1905$. https://doi.org/10.1016/j.conbuildmat.2010.11.067

9. Najimi, M., Pourkhorshidi, A.R. Properties of Concrete Containing Copper Slag Waste Magazine of Concrete Research 68 (3) 2011: pp. 605-615. https://doi.org/10.1680/macr.2011.63.8.605

10. Alp, I., Deveci, H., Süngün, H. Utilization of Flotation Wastes of Copper Slag as Raw Material in Cement Production Journal of Hazardous Materials $159(2-3)$ 2008: pp. 390-395. https://doi.org/10.1016/j.jhazmat.2008.02.056

11. Moura, W.A., Gonçalves, J.P., Lima, M.B.L. Copper Slag Waste as a Supplementary Cementing Material to Concrete Journal of Materials Science 42 (7) 2007: pp. 2226. https://doi.org/10.1007/s10853-006-0997-4

12. Caliskan, S., Behnood, A. Recycling Copper Slag as Coarse Aggregate: Hardened Properties of Concrete Proceedings of seventh international conference on concrete technology in developing countries 2004: pp. 91-98.

13. GB/T 50080-2016. Standard for Test Method of Performance on Ordinary Fresh Concrete (in Chinese).

14. GB/T 8077-2012. Methods for Testing Uniformity of Concrete Admixture (in Chinese)

15. GB/T 50081-2002. Standard for Test Method of Mechanical Properties on Ordinary Concrete (in Chinese).

16. GB/T 750-92. Autoclave Method for Soundness of Portland Cement (in Chinese).

17. Goldman, A., Bentur, A. The Influence of Microfillers on Enhancement of Concrete Strength Cement and Concrete Research 23 (4) 1993: pp. 962-972. https://doi.org/10.1016/0008-8846(93)90050-J

18. Guo, X.Y. Study on Evaluation Method of Brittleness and Toughing Measures of High Strength Concretes. Wuhan University, pp. $41-42$.

19. Edwin, R.S., Schepper, M.D., Gruyaert, E., Belie, N.D. Effect of Secondary Copper Slag as Cementitious Material In
Ultra-High Performance Mortar Construction and Building Materials 119 2016: pp. 31-44.

http://dx.doi.org/10.1016/j.conbuildmat.2016.05.007

20. Zain, M.F.M., Islam, M.N., $\quad$ Radin, S.S., Yap, S.G. Cement-based Solidification for the Safe Disposal of Blasted Copper Slag Cement \& Concrete Composites 26 (7) 2004: pp. 845-851. https://doi.org/10.1016/j.cemconcomp.2003.08.002

21. Benson, R.E., Chandler, H.W., Chacey, K.A. Hazardous Waste Disposal as Concrete Admixture Journal of Environmental Engineering 111 (4) 1986: pp. $441-447$. https://doi.org/10.1061/(asce)0733-9372(1985)111:4 (441)

22. Guo, Z.H., Zhang, X.Q. Experimental Investigation of Complete Stress-Deformation Curves of Concrete in Tension Journal of Building Structure 84 (4) 1988: pp. 278-285.

23. Ma, Q., Du, H., Zhou, X., He, K., Lin, Z., Yan, F., Huang, L., Guo, R. Performance of Copper Slag Contained Mortars after Exposure to Elevated Temperatures Construction \& Building Materials 172 2018: pp. $378-386$. https://doi.org/10.1016/j.conbuildmat.2018.03.261

24. Said, A.A., El-Salaam, K.M.A., Hassan, E.A., ElAwad, A.M., Mohamed, M.M. A Study on the Thermal Decomposition of Iron-Cobalt Mixed Hydroxides Journal of Thermal Analysis 39 (3) 1993: pp. 309-321. https://doi.org/10.1007/bf01983530

25. Wang, G. Determination of the Expansion Force of Coarse Steel Slag Aggregate Construction and Building Materials 24 (10) 2010: pp. $1961-1966$. https://doi.org/10.1016/j.conbuildmat.2010.04.004

26. Wang, G., Wang, Y., Gao, Z. Use of Steel Slag as a Granular Material: Volume Expansion Prediction and Usability Criteria Journal of Hazardous Materials $184(1-3)$ 2010: pp. 555-60. https://doi.org/10.1016/j.jhazmat.2010.08.071

27. Ameri, M., Behnood, A. Laboratory Studies to Investigate the Properties of CIR Mixes Containing Steel Slag as a Substitute for Virgin Aggregates Construction and Building Materials 26 (1) 2012: pp. 475-480. https://doi.org/10.1016/j.conbuildmat.2011.06.047

28. Pan, W.C. A Study on the Components and Cementitious Properties of Activated Copper Slag Journal of South China University of Technology 41 (1) 1993: pp. 91-99.

29. Hou, X.K., Xu, D.L., Xue, B., Li, H. S. Study on Volume Stability Problem of Cement Caused by Steel Slag Journal of Building Materials 15 (5) 2012: pp. 589-595. https://doi.org/10.3969/j.issn.1007-9629.2012.05.002 